\title{
ANALYSIS OF ANNUAL RAINFALL DATA BY MARKOVIAN APPROACH IN THE LOBO WATERSHED (WEST-CENTER OF CÔTE D'IVOIRE)
}

\author{
VAMI HERMANN N'GUESSAN BI ${ }^{1,2}$, MARC YOUAN TA ${ }^{1,2}$, \\ FABRICE BLANCHARD ALLECHY ${ }^{1}$, FABRICE ASSA YAPI ${ }^{1}$, \\ ALIOUNE BADRA KONE ${ }^{2}$, KOUADIO AFFIAN ${ }^{1,2}$
}

\begin{abstract}
The rainfall deficit has become remarkable in recent decades in Côte d'Ivoire in general and particularly in the Lobo watershed. The objective of this study is to analyze rain behaviour using weather generator MulGETS based on first order Markov chains to two states. Daily data from 1984 to 2013 from 17 stations were used to predict daily precipitation data for the period 2021 to 2050. The results obtained show that the probability of having two successive dry years or two successive wet years is higher over the entire study area for the period 1984-2013. For the period 2021 to 2050, the probability of having two successive dry years and two successive wet years will be higher over the entire basin and in the south, center and north respectively. The probability of a wet year followed by a dry year will be higher in the south, west, northwest and north of the basin. The probability of a dry year followed by a wet year will be relatively high in the north, center and southwest of the basin.
\end{abstract}

Keywords: rainfall analysis, MulGETS, Lobo, Côte d'Ivoire.

\section{INTRODUCTION}

Climate change is one of the greatest challenges facing humanity in the $21^{\text {st }}$ century. West Africa is one of the most vulnerable regions in the world to climate change, which is now a potentially major threat to the environment, water resources and sustainable development (Koumassi et al., 2014). Climate change causes several natural phenomena (flooding, drought, desertification)

1 Laboratoire des Sciences et Techniques de l'Eau et de l'Environnement, UFR STRM, Université Felix Houphouët-Boigny, Côte d'Ivoire, vami@outlook.com/fabriceallechy@gmail.com

2 Centre Universitaire de Recherche et d'Application en Télédétection (CURAT), Université Felix Houphouët-Boigny, Côte d'Ivoire, youanta@gmail.com 
and impacts rainfall in West African countries. This is the case in Côte d'Ivoire in general and particularly in the Lobo basin where rainfall has become deficient since 1970 (Konan, 2002; Ardoin, 2004; Yao et al., 2012). Côte d'Ivoire, whose economic development is based on agriculture, has an agricultural sector that is generally of the rainfall type and is heavily penalized by this decrease in rainfall (Konan, 2002; Brou, 2005). In an attempt to provide adequate solutions to these problems, many studies are looking at modelling natural phenomena such as local climates, changes in annual precipitation and their probability of occurrence.

Like climate modelling, predicting rainfall in the short to medium term is of great interest and can help identify the causes (N'Guessan Bi et al., 2018). It also makes it possible to measure the impact of climatic events, their duration or intensity on activities (Chiquet, 2003). The objective of this study is to analyze the annual precipitation behaviour of the Lobo watershed to determine their probabilities of occurrence for the periods 1984-2013 and 2021-2050. However, the most widely used technique remains the one based on Markov chains, which has been widely used for precipitation analysis (Hess and al., 1989, Mares, 1974, 1993; Liana and Elena, 2004; Chèze and Jourdain, 2003). The advantage of this approach is that it expresses the conditional probabilities of moving from the previous state (previous day) to the state of the current day (Meddi and Meddi, 2009). Markov chains also take into account the relationship between successive days (Kébailli and Thirriot, 1984; Arnaud, 1985; Thirriot, 1986) and allow problems with uncertain or incomplete information to be treated (Dequier, 2005). Chiquet (2003) developed a method based on non-homogeneous Markov chains to estimate and predict daily temperature values in France. In the field of spatiotemporal analysis, Lazri et al (2007) developed a model for the analysis of precipitation data by Markovian approach. The data used are a series of images collected by the meteorological radar. Markov models are widely used to simulate the temporal evolution of a system based on transition probabilities (Korotov and al., 2001). This work will be structured around four sections. The first section will introduce the study area. The second section will describe the MulGETS time generator that predicted daily rainfall data from 2021 to 2050 and the first-order Markov model to describe the occurrence of annual precipitation. The results and discussion will be presented in the third section followed by the conclusion in the fourth section.

The Lobo watershed is a sub-basin of the Sassandra River. It is located in the mid-western part of Côte d'Ivoire between longitudes $6^{\circ} 05^{\prime}$ and $6^{\circ} 55^{\prime}$ West and latitudes $6^{\circ} 02^{\prime}$ and $7^{\circ} 55^{\prime}$ North (Fig. 1). With an area of $12722 \mathrm{~km}^{2}$ and a length of $355 \mathrm{~km}$, the Lobo River originates in the south of the Séguéla region and flows into the Sassandra not far from the town of Loboville. Most of the basin belongs to the Upper Sassandra region, the regional capital is Daloa. 
It covers the departments of Daloa, Issia, Vavoua and Zoukougbeu; the far north belongs to the department of Séguéla; while it overflows into the south, on that of Soubré. The climate of the basin is characterized by two types of climate: the attenuated equatorial transition climate (Baoule climate with two seasons) observed in the northern half of the basin and the equatorial transition climate (attiéen climate with four seasons) observed in the extreme south. Its relief is like a peneplain whose altitude varies between $160 \mathrm{~m}$ and $480 \mathrm{~m}$ (Avenard, 1971). It is monotonous as a whole with singularities in places. Two main types of relief share the basin: plains at altitudes ranging from 160 to $240 \mathrm{~m}$, located in the south of the basin, and plateaus at altitudes of $240 \mathrm{~m}$ and $320 \mathrm{~m}$ occupying most of the basin (Yao, 2014). The Lobo river basin is located in the Guinean domain and belongs to the mesophilic sector with forest areas suitable for agriculture. It is mainly composed of highly or moderately desaturated modal reworked ferrallitic soils with overburden from schists and granites (Perraud, 1971).

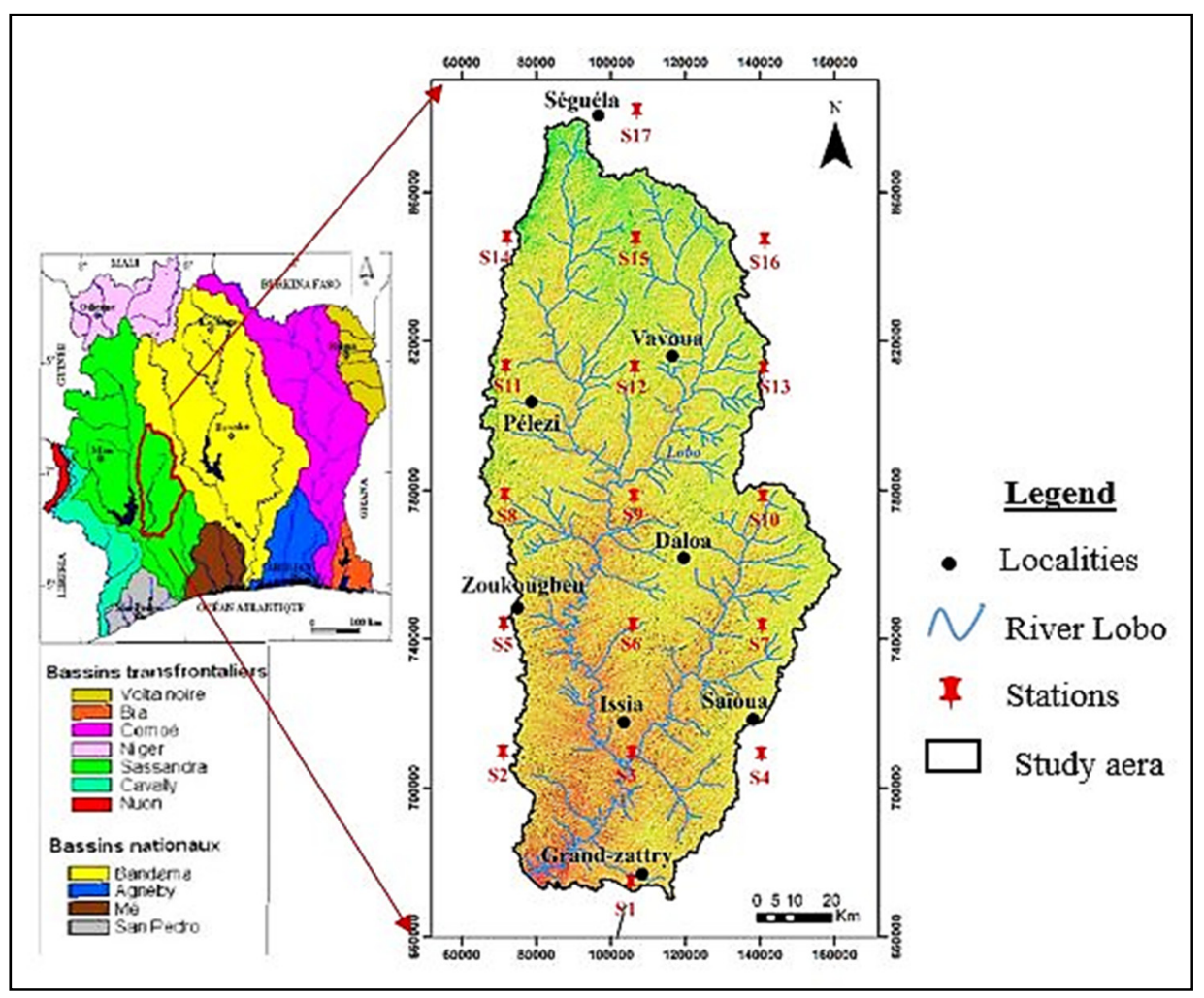

Fig. 1. Localisation of Lobo watershed 


\section{DATA AND METHODS}

\subsection{Data and software}

\subsubsection{Data}

The data consist mainly of daily precipitation data from seventeen (17) weather stations covering the study area over a period from 1984 to 2013 (30 years). They come from the Climate Prediction System Reanalysis Centre (CFSR) available on the website: https://globalweather.tamu.edu/\#pubs. They were used as a reference for forecasting daily data from 2021 to 2050.

\subsubsection{Software}

The software used is of several types:

- XLSTAT 2016 was used to store and statistically process rainfall data;

- Matlab 2014 for the forecasting of daily precipitation data and Markovian modelling.

\subsection{Methods}

\subsubsection{MulGETS model}

Multi-site weather Generator of École de Technologie Supérieure (MulGETS) was developed by Chen et al, 2012. It is a stochastic time generator that generates climate data that is statistically similar to data observed at several sites. MulGETS is an extension of a single-site weather generator WeaGETS (Weather Generator of École de Technologie Supérieure) that is suitable for small watersheds where a single station can be used to represent the entire watershed (Chen et al, 2012). It uses a first-order linear autoregressive model to generate temperature and a multi-gamma distribution (a combination of several gamma distributions) and a multi-exponential distribution to generate daily precipitation amounts. However, Chen et al (2012) indicated that the gamma distribution is generally the most widely used because it is more efficient compared to the exponential distribution. This time generator was used to predict precipitation data in this study. Details of this time generator are known from the work of Brissette and al., 2007; Chen et al, 2012 and Chen et al, 2014. The principle of this stochastic time generator is based on the first order Markov chain method with two states. 


\subsubsection{First order Markov}

Several studies have focused on precipitation analysis from Markov chains (Benzerti and Habaieb, 2001; Cazacioc and Cipu, 2004; Chèze and Jourdain, 2003; Meddi and Meddi, 2009; N'guessan Bi et al, 2014) because they describe precipitation echoes well. We apply it on an annual scale to determine or predict the probability of having a dry year after a dry year or not. This process expresses conditional probabilities of moving from the previous day's status (previous year) to the current year's status. To do this, we used the Markov chain method (Arnaud, 1985). Markov chains take into account the link between successive years; indeed, the rainfall in year $\mathrm{k}$ depends on the state of past years. This model will be of the first order if the rain in year $\mathrm{k}$ depends only on the previous year, i.e. the closest past of the state. It will be of order $h$ if the rain of year $\mathrm{k}$ depends on the $\mathrm{k}-1, \mathrm{k}-2, \ldots, \mathrm{k}-\mathrm{h}$ past years. Thus, the state of year k only depends on the state of year $\mathrm{k}-1$ for the first order Markov. The first order Markov chain is introduced by a probability (equation 1):

with

$$
P\left(X_{n+1}=j \mid X n=i, X_{n-1}=i_{n-1}, \ldots, X_{0}=i_{0}\right)=P\left(X_{n+1}=j \mid X_{n}=i\right)
$$

$$
\mathrm{P}\left(\mathrm{Xn}=\mathrm{i}, \mathrm{Xn}-1=\mathrm{in}-1, \ldots, \mathrm{X}_{0}=\mathrm{i}_{0}\right)=0
$$

and we note (equation 2):

$$
P_{i j}=P\left(X_{n+1}=j \mid X_{n}=i\right)
$$

where Pij is the $i$ th element of the $\mathrm{j}$ th column of the transition matrix of the Markov chain.

These probabilities were calculated using the following relationship (equation 3), Benzarti and Habaieb, 2001, Lazri et al, 2007):

$$
p i=\frac{N i}{N}
$$

where $\mathrm{N}_{\mathrm{ij}}$ is the number of transitions from state $\mathrm{i}$ to state $\mathrm{j}$ and $\mathrm{Ni}$ is the number of transitions from state i to any other state.

A year can be characterized in terms of rainfall by two states:

- state S: dry or very dry years

- state P: normal, wet and very wet years

For the first order Markov, four situations are possible (Benzerti and Habaieb, 2001):

- S-S (two successive dry years);

- S-P (a dry year followed by a wet year);

- P-S (a wet year followed by a dry year);

- P-P (two successive wet years). 


\section{RESULTS AND DISCUSSION}

\subsection{Application of Markov chains}

\subsubsection{Markovian first-order model for the period 1984-2013}

The results of the first-order Markov matrix for the seventeen stations for the period 1984 to 2013 are shown in Table 1.

Table 1: First order Markov process for each station, 1984 à 2013

\begin{tabular}{ccccc}
\hline \multicolumn{5}{c}{ Transition probabilities (\%) } \\
\hline Stations & P-P & P-S & S-S & S-P \\
\hline S1 & 80 & 20 & 79 & 21 \\
\hline S2 & 69 & 31 & 69 & 31 \\
\hline S3 & 81 & 19 & 85 & 15 \\
\hline S4 & 79 & 21 & 80 & 20 \\
\hline S5 & 75 & 25 & 77 & 23 \\
\hline S6 & 81 & 19 & 85 & 15 \\
\hline S7 & 94 & 06 & 92 & 08 \\
\hline S8 & 93 & 07 & 100 & 00 \\
\hline S9 & 93 & 07 & 100 & 00 \\
\hline S10 & 93 & 07 & 100 & 00 \\
\hline S11 & 86 & 14 & 93 & 07 \\
\hline S12 & 93 & 07 & 93 & 07 \\
\hline S13 & 79 & 21 & 80 & 20 \\
\hline S14 & 86 & 14 & 93 & 07 \\
\hline S15 & 88 & 13 & 85 & 15 \\
\hline S16 & 79 & 21 & 80 & 20 \\
\hline S17 & 81 & 19 & 85 & 15 \\
\hline & & & &
\end{tabular}

The results of the transition matrix for the period 1984 to 2013 show that:

- for the period 1984 to 2013 the probability varies from 0 to $100 \%$ to have a dry year regardless of the year of departure (dry or wet) for the seventeen stations;

- the probability of having a wet year followed by a dry year (P-S) is low (it varies from $7 \%$ to $31 \%$ ) over the entire basin; 
- to have a dry year followed by a wet year (S-P), the probability is also low (7\% to 31\%) on most stations but it is nil for stations S8, S9 and S10 located in the center of the Lobo watershed;

- the probability of having two successive dry years (S-S) is very high for the seventeen stations (it is between $69 \%$ and 100\%);

- for two successive wet years (P-P), the probability is also higher (between 69\% and 94\%) over the entire study area.

\subsubsection{Markovian first-order model for the period 2021-2050}

The results of the first-order Markov matrix for the seventeen stations for the period 2021 to 2050 are shown in Table 2.

Table 2. First order Markov process for each station, 2021 à 2050

\begin{tabular}{ccccc}
\hline \multicolumn{5}{c}{ Transition probabilities (\%) } \\
\hline Stations & P-P & P-S & S-S & S-P \\
\hline S1 & 36 & 64 & 67 & 33 \\
\hline S2 & 38 & 62 & 50 & 50 \\
\hline S3 & 63 & 38 & 54 & 46 \\
\hline S4 & 64 & 36 & 73 & 27 \\
\hline S5 & 38 & 62 & 50 & 50 \\
\hline S6 & 63 & 38 & 54 & 46 \\
\hline S7 & 63 & 38 & 62 & 38 \\
\hline S8 & 50 & 50 & 65 & 35 \\
\hline S9 & 53 & 47 & 50 & 50 \\
\hline S10 & 63 & 38 & 46 & 54 \\
\hline S11 & 46 & 54 & 56 & 44 \\
\hline S12 & 36 & 64 & 56 & 44 \\
\hline S13 & 40 & 60 & 63 & 37 \\
\hline S14 & 50 & 50 & 47 & 53 \\
\hline S15 & 53 & 47 & 43 & 57 \\
\hline S16 & 57 & 43 & 53 & 47 \\
\hline S17 & 53 & 47 & 50 & 50
\end{tabular}

The results of the transition matrix show that:

- the probability, for the seventeen stations for the period 2021 to 2050, will vary from $27 \%$ to $73 \%$ to have a dry year regardless of the year of departure (dry or wet). 
- the probability of having a wet year followed by a dry year (P-S) will be higher (50\% to 64\%) in the South of the basin (Grand-Zattry), in the West (Zoukougbeu), in the North-West (Pélezi) and in the North (Vavoua) than in the Centre of the basin (38\% to $47 \%)$ in Daloa;

- to have a dry year followed by a wet year (S-P), the probability will be higher $(50 \%$ to $57 \%)$ in the north (Seguela), in the centre (Daloa), in the southwest of the basin, and will decrease (27\% to $44 \%$ ) towards the southeast (Saiga) and the south of the basin (Great zattry);

- the probability of having two successive dry years will be higher $(50 \%$ to $72 \%$ ) for the majority of stations but relatively lower (43\% to $47 \%$ ) for stations S10, S14 and S15 located north of Vavoua and Pélezi and northeast;

- if a year is wet, the probability of a wet year (P-P) will be higher $(50 \%$ to $64 \%$ ) in the south (Issia), southeast (Saiga), center (Daloa) and north (Séguéla) of the basin.

\subsection{Discussion}

This study consists of the analysis of annual rainfall in the Lobo catchment area located in the western central part of Côte d'Ivoire. The precipitation data used in this study are obtained from the National Environmental Prediction Centre's (CFSR) climate prediction system reanalysis repository. The CFSR was designed and executed as a coupled atmosphere-ocean-land-sea ice system surface to provide the best estimate of the state of these coupled domains during this period. Mo et al, 2011; Najafi et al, 2012; Dile and Srinivasan, 2014 have conducted several studies with CFSR data and indicate their validity. According to Fuka et al (2013) these data have the advantage of better reflecting the rainfall event measured by satellites. His studies on the use of reanalysis of the climate prediction system as meteorological input data for watershed models have shown that CFSR data can be reliably applied to watershed modelling in various hydroclimatic regimes and other watersheds. The work of Saleh (2000) in the northern upper part of the Bosque River watershed reached the same conclusion. The methodological approach is based on the use of Markov chains, widely used for precipitation analysis (Chèze and Jourdain, 2003; Cazacioc and Cipu, 2004), which describe daily precipitation fields well. They have the advantage of taking into account the memory effect. The work of Stern et al (2006) and N'Guessan Bi (2014) came to the same conclusion. The MulGETS first-order Markov model, which uses a first-order linear autoregressive model and a multi-gamma distribution (more efficient compared to the exponential distribution according to Chen et al., 2012), was selected to adequately generate the daily precipitation data. These results are consistent with the work of Brissette et al (2007) and 
Chen et al (2014). This study shows that the probability of having two successive dry years or two successive wet years is higher over the entire study area for the period 1984-2013. These results are similar to the work of Lazri et al (2007), Meddi and Meddi (2009) and Meledje et al (2015). Indeed, in their studies on the analysis of rainfall and the occurrence of drought, Lazri et al (2007) showed that in the "Sea" zone, the probability of having a non-precipitating state after a non-precipitating state is higher than in the "Land" zone. On the other hand, the probability of having a precipitating state following a precipitating state is higher in the "Land" zone than in the "Sea" zone. Meddi and Meddi (2009) in northwest Algeria have shown that the probability of a dry year being followed by a dry year is higher in the west (Habra-Sig, Ghriss, Sidi bel Abbes and Maghnia plains) and the probability of having two successive non-drying years is high for all stations. Meledje et al (2015) indicate that the probability of having two successive dry years is higher in the northern part of the transboundary Bia river basin between Côte d'Ivoire and Ghana. For the period 2021 to 2050, the probability of having two successive dry years and two successive wet years will be higher over the entire basin and in the south, centre and north respectively. The probability of a wet year followed by a dry year will be higher in the south, west, northwest and north of the basin. The probability of a dry year followed by a wet year will be relatively high in the north, centre and southwest of the basin. These results may be explained by the fact that annual rainfall amounts will be decreasing over the entire study area and that the highest rainfall amounts will be observed in the central and southwestern part of the Lobo watershed.

\section{CONCLUSION}

The application of first-order Markov has made it possible to determine the probability of occurrence of annual precipitation in the Lobo watershed. Thus, the probability of having two successive dry years or two successive wet years is higher over the entire study area for the period 1984-2013. For the period 2021 to 2050, the probability of having two successive dry years and two successive wet years will be higher over the entire basin and in the south, centre and north respectively. The probability of a wet year followed by a dry year will be higher in the south, west, northwest and north of the basin. The probability of a dry year followed by a wet year will be relatively high in the north, centre and southwest of the basin. All these results show that precipitation is well described by Markov chains over the entire Lobo watershed. They can help to find strategies to fight drought and floods. 


\section{REFERENCES}

1. Ardoin, B.S. (2004), Variabilité hydroclimatique et impacts sur les ressources en eau de grands bassins hydrographiques en zone soudano-sahélienne. Thèse de Doctorat, Université de Montpellier II, France, 330p.

2. Arnaud, M. (1985), Contribution à l'étude stochastique markovienne des précipitations dans le bassin Adour-Garonne. Thèse de Doctorat, Toulouse, France.

3. Avenard, J.M. (1971), Aspect de la géomorphologie, in Avenard J.M., Eldin M., Girard G., Sircoulon J., Touchebeuf P., Guillaumet J.L., Adjanohoun E. et Perraud A. (Eds.), Milieu naturel de Côte d'Ivoire. Mémoire ORSTOM, n 50, Paris, France, pp. 8-73.

4. Benzerti, Z. \& Habaieb, H.E. (2001), Etude de la persistance de la sécheresse en Tunisie par utilisation des chaînes de Markov (1909-1996), Sècheresse, 12, 215-20.

5. Brissette, F.P., Khalili, M. and Leconte, R. (2007), Efficient stochastic generation of multi-site synthetic precipitation data, J. Hydrol., 345 (3-4), pp 121-133.

6. Brou, Y.T. (2005), Climat, mutations socio-économiques et paysages en Côte d'Ivoire. Mémoire de synthèse des activités scientifiques, Mémoire d'Habilitation à Diriger des Recherches. Université des Sciences et Technologies de Lille, France, $226 \mathrm{p}$.

7. Cazacioc, L. \& Cipu, E.C. (2004), Evaluation of the transition probabilities for daily precipitation time series using a Markov chain model, The $3^{\text {rd }}$ International Colloquium Mathematics in Engineering and Numerical Physics, p.82-89, Oct 7-9, Bucharest, Romania.

8. Chen, J., Brissette P.F., Zhang, X.J. (2014), A multi-site stochastic weather generator for daily precipitation and temperature, American Society of Agricultural and Biological Engineers, ISSN 2151-0032 DOI 10.13031/trans.57.10685. Vol. 57(5): pp 1375-1391.

9. Chen, J., Brissette, P.F., Leconte, R., Caron, A. (2012), A versatile weather generator for daily precipitation and temperature, Transactions of the ASABE, 55(3), pp 895906.

10. Chèze, I. \& Jourdain, S. (2003), Calcul Des Quantiles De Données De Retour De La Température Par La Méthode Gev. Calcul Des Températures A Risque, pp.1-50, Météo France, Dp/Serv/Bec, Toulouse, France.

11. Chiquet, J. (2003), Estimation des températures journalières à l'aide de techniques markoviennes. Mémoire de DEA TIS, Compiègne, France.

12. Dile, Y.T., Srinivasan, R. (2014), Evaluation of CFSR climate data for hydrologic prediction in data-scarce watersheds: an application in the Blue Nile River Basin, Journal of the American Water Resources Association (JAWRA), pp. 1-16.

13. Dequier, J. (2005), Chaîne de Markov et application, Mémoire de probatoire en informatique, Université de Grenoble, France, 35p.

14. Fuka, D.R., MacAllister, C.A., Degaetano, A.T. and Easton, Z.M. (2013), Using the Climate Forecast System Reanalysis dataset to improve weather input data for watershed models. Hydrol. Proc., DOI: 10.1002/hyp.10073. 
15. Hess, G.D., Leslie, L.M., Guymer, A.E., Fraedrich, K. (1989), Application of a Markov technique to the operational, short-term forecasting of rainfall, Australian Meteorological Magazine, 37, 2, 83-91.

16. Konan, B. (2002), Modélisation et gestion intégrée des ressources en eau dans le bassin versant du Sassandra (Côte d'Ivoire), Thèse de doctorat 3ème cycle, Université d'Abobo-Adjamé, 146 p.

17. Koumassi, D. H., Tchibozo, A.E., Vissin, E. and Houssou, C. (2014), Analyse fréquentielle des évènements hydro-pluviométriques extrêmes dans le bassin de la Sota au Bénin. Afrique SCIENCE 10 (2), ISSN 1813-548X. pp 137 - 148.

18. Korotkov, V., Logofet, D., and Loreau, M. (2001), Succession in mixed boreal forest of Russia: Markov models and Non-Markov effects. Ecological Modelling, 142, pp. 25-38.

19. Lazri, M., Ameur, S., and Haddad, B. (2007), Analyse de données de précipitations par approche markovienne, Larhyss Journal, no. 6, December, pp.7-20.

20. Mares, I. (1974), A Markov chain for evaluation of Moon rainfalls (in Romanian), Studii si Cercetari de Meteorologie, Part I/139, 203-219.

21. Mares I., Mares C. (1993), On extreme events in the precipitation field, in Kundzewicz, Z.W., Rosbjerg, D., Simonovic, S.P. and Takeuchi, K. (eds.), Extreme Hydrological Events: Precipitation, Floods and Droughts, International Symposium, Yokohama, Japan, pp 307-313.

22. Meledje, N.D.H., Lazare Kouassi, K., N'Go, Y. A., Savane, I. (2015), Caractérisation des occurrences de sécheresse dans le bassin hydrologique de la Bia transfrontalier entre la Côte d'Ivoire et le Ghana: contribution des chaînes de Markov, Cah Agric 24: 186-97, DOI: 10.1684/agr.2015.0755.

23. Meddi, A. and Meddi, M. (2009), Etude de la persistance de la sécheresse au niveau de sept plaines algériennes par utilisation des chaines de Markov (1930-2003), Courrier du Savoir - No. 09, March 2009, pp.39-48.

24. N'guessan Bi, V.H., Saley, M.S., Pop, S., Terebech, R., Bogdan, B., Djagoua, E.V., Kouame, F., Borda, M. and Affian K. (2014), Markovian approach for analysis and prediction of monthly precipitation field in the department of Sinfra (Central-west of Côte d'Ivoire), International Journal of Engineering Research and General Science, Volume 2, Issue 1, January 2014, ISSN 2091-2730, pp.34-49.

25. N'guessan Bi, V.H., Saley, M.B., Wade, S., Djagoua, E.V., Kouame, F. and Affian, K. (2014), Cartographie du risque d'inondation par une approche couplée de la télédétection et des systèmes d'informations géographiques (SIG) dans le département de Sinfra (centre-ouest de la Côte d 'Ivoire), European Scientific Journal, January 2014 edition, vol. 10, No. 2, ISSN: 1857 - 7881 (Print) e -ISSN 1857- 7431, p. 170-191.

26. N'Guessan Bi, V. H., Diedhiou, A., Kouadio, B. H., Kone, A. B., Koffi, K. and Affian, K. (2018), Apport de la télédétection à l'analyse spatio-temporelle du mode d'alternance et d'occurrences des épisodes humides: apport des indices climatiques et chaînes de Markov; cas du district d'Abidjan. Actes du 1er colloque international Nexus Eau Energie Alimentation et Habitat du 12 au 14 décembre, Ouagadougou, Burkina Faso, pp 69-80. 
27. Perraud, A. (1971), Les sols in Avenard, J.M., Eldin, M., Girard, G., Sircoulon, J., Touchebeuf, P., Guillaumet, J.L., Adjanohoun, E. and Perraud, A., Milieu naturel de Côte d'Ivoire. Mémoire ORSTOM, n50, Paris, France, pp. 265-391.

28. Saleh, A., Arnold, J. G., Gassman, P.W., Hauck, L.M., Rosenthal, W.D, Williams, J.R., McFarland, A.M.S. (2000), Application of SWAT for the upper north Bosque river watershed, Transactions-American of Society Agricultural Engineers 43 (5), pp. 1077-1088.

29. Stern, R., Rijks, D., Dale, I., and Knock, J. (2006), Instat Climatic Guide, 330p.

30. Thirriot, C. (1986), Simplicité et efficacité des chaînes de Markov comme modèle de la pluviométrie, Arch Hydrot., 23, pp. 1-2.

31. Yao, A.B. (2014), Evaluation des potentialités en eau du bassin versant de la Lobo en vue d'une gestion rationnelle (centre-ouest de la côte d'ivoire), Thèse Unique de Doctorat, Université Abobo-Adjamé, Côte d'Ivoire, 186p.

32. Yao, A.B., Goula, B.T.A., Kouadio, Z.A., Kouakou, K.E., Kane, A. and Sambou, S. (2012), Analyse de la variabilité climatique et quantification des ressources en eau en zone tropicale humide. Cas du bassin versant de la Lobo au Centre-Ouest de la Côte d'Ivoire, Revue Ivoirienne des Sciences et Technologies, 19, pp. 136-157. 